Jurnal ABDIMAS INDEPENDEN

Vol. 1, No. 1, Mei 2020

\title{
PELATIHAN PENINGKATAN PENDAPATAN DAN PENCATATAN USAHA PADA INDUSTRI KOPIAH DI KECAMATAN
}

\section{KEDIRI LOMBOK BARAT}

\author{
D. Tialurra Della Nabila \\ Fakultas Ekonomi Dan Bisnis Universitas Mataram \\ tialurradellanabila@unram.ac.id \\ Animah \\ Fakultas Ekonomi Dan Bisnis Universitas Mataram \\ animahmtr@unram.ac.id \\ Nungki Kartikasari \\ Fakultas Ekonomi Dan Bisnis Universitas Mataram \\ nungkikartikasari@gmail.com \\ Adhitya Bayu Suryantara \\ Fakultas Ekonomi Dan Bisnis Universitas Mataram \\ adhityabayus@gmail.com
}

\begin{abstract}
ABSTRAK
Industri kopiah yang terdapat di Kediri Selatan Bangket Dalam Kecamatan Kediri Kabupaten Lombok Barat turut berkontribusi dalam meningkatkan pertumbuhan ekonomi masyarakat setempat. Kecilnya modal usaha, sumber daya manusia yang terbatas, dan tidak adanya pencatatan keuangan menjadi kendala dalam mengembangkan usaha kopiah ini. Tujuan diadakannya program PKM ini adalah untuk meningkatkan pendapatan melalui pemasaran produk melalui e-commerce dengan pemanfaatan media sosial dan situs jual beli terkemuka, meningkatkan motivasi kerja pemilik usaha dan pekerja sehingga dapat menekan penurunan minat dan meningkatkan kualitas sumber daya manusia, serta menerapkan pencatatan keuangan yang baik secara rutin. Hasil dari kegiatan PKM ini adalah Mitra memahami pentingnya pemasaran melalui $e$ commerce dan mengaplikasikannya melalui media sosial dan situs jual beli online serta mengikuti perkembangan selera pasar terhadap model kopiah terkini. Selain itu, Mitra memahami pentingnya meningkatkan mmotivasi kerja karyawan untuk menghasilan produk yang berkualitas dan bersaing. Terakhir, Mitra dapat mempraktian pencatatan atas setiap biaya produksi dan penjualan yang diterima untuk keberlangsungan usaha Mitra kedepannya.
\end{abstract}

Kata Kunci: industri kopiah, e-commerce, motivasi kerja, pencatatan 


\section{PENDAHULUAN}

\section{Analisis Situasi}

Kopiah merupakan salah satu hasil kerajinan unggulan dari Kecamatan Kediri Kabupaten Lombok Barat. Produksi kopiah pada Kecamatan Kediri telah dirintis sejak tahun 1980-an dan telah menghasilkan beraneka ragam model dan motif kopiah khas dari Kota Santri ini. Sebagai sentra kerajinan kopiah, Kecamatan Kediri memiliki lokasi yang cukup strategis karena merupakan salah satu trayek transportasi menuju ke Bandar Udara Internasional Lombok (BIL) di Lombok Tengah. Kualitas kopiah hasil produksi Kecamatan Kediri telah dikenal dan merambah pasar domestik hingga Timur Tengah, bahkan telah menerima berbagai penghargaan dari pemerintah maupun swasta. Oleh karena itu, industri kopiah turut berkontribusi dalam meningkatkan pertumbuhan ekonomi masyarakat di Kecamatan Kediri.

Penjualan kopiah di Kecamatan Kediri mengalami peningkatan yang cukup signifikan hingga dua kali lipat atau lebih pada saat bulan Ramadhan, Idul Adha (Lebaran Haji), Maulid, dan tahun ajaran baru masuk sekolah. Pelaku industri kopiah di Kecamatan Kediri didominasi oleh produsen skala kecil sehingga para perantara berperan aktif dalam pendistribusian produk kopiah ke pedagang ecer ataupun konsumen akhir.

\section{Perumusan Masalah}

Hasil observasi lapangan menunjukkan bahwa masalah utama yang dihadapi oleh industri kopiah di Kecamatan Kediri Kabupaten Lombok Barat adalah :

1. Bagaimana meningkatkan pendapatan dengan modal usaha yang terbatas?

2. Bagaimana mengatasi keterbatasan sumber daya manusia?

3. Bagaimana melakukan pencatatan keuangan yang baik? 


\section{Jurnal ABDIMAS INDEPENDEN}

Vol. 1, No. 1, Mei 2020

\section{Tujuan Kegiatan}

Tujuan yang akan dicapai setelah pelaksanaan Program Kemitraan Masyarakat (PKM) ini secara umum adalah peningkatan jaminan kelangsungan hidup usaha kopiah. Sedangkan tujuan khususnya adalah:

1. Mitra mampu meningkatkan pendapatan melalui pemanfaatan $e$ commerce dan pencantuman label pada kemasan yang baik.

2. Mitra mampu menekan penurunan jumlah sumber daya manusia dengan peningkatan motivasi kerja pemilik usaha dan pekerja dan ruang kerja yang teratur.

3. Mitra mampu memahami dan menerapkan pencatatan keuangan yang baik dan rutin.

Manfaat yang diharapkan dari kegiatan pengabdian masyarakat ini adalah:

1. Meningkatkan pemahaman mengenai pentingnya pemasaran melalui ecommerce dengan memanfaatkan media sosial dan situs jual beli online serta mengikuti perkembangan selera pasar terhadap model kopiah terkini.

2. Meningkatkan pemahaman mengenai pentingnya meningkatkan motivasi kerja karyawan untuk menghasilan produk yang berkualitas dan bersaing.

3. Meningkatkan pemahaman mengenai pentingnya pencatatan atas setiap biaya produksi dan penjualan yang diterima untuk keberlangsungan usaha mitra kedepannya.

\section{METODE KEGIATAN}

Agenda-agenda pokok yang menjadi fokus kegiatan PKM dalam mengatasi permasalahan yang dihadapi mitra adalah pelatihan dalam pemasaran produk melalui e-commerce, pelatihan untuk peningkatan motivasi kerja pemilik usaha dan pekerja, pelatihan pencatatan transaksi keuangan, serta pendampingan kegiatan pemasaran dan pencatatan. 
Dalam melaksanakan keempat agenda pokok tersebut, kegiatan PKM akan dilakukan dalam 5 (lima) tahapan, yaitu persiapan, pelatihan pemasaran produk, pelatihan sumber daya manusia, pelatihan pencatatan serta evaluasi dan pelaporan. Berikut adalah penjelasan dari keenam tahapan tersebut.

\section{A. Persiapan}

Tahap pertama dalam PKM ini adalah persiapan, tim berkoordinasi dengan mitra, yaitu Bapak H. Saipul Badri, terkait dengan kesepakatan waktu dan susunan pelaksanaan program secara sistematis. Mitra menyiapkan kelengkapan teknis yang akan dibutuhkan saat pelaksanaan pelatihan dilakukan dan juga menyiapkan lokasi pelaksanaan pelatihan.

\section{B. Pelatihan Pemasaran Produk}

Pada tahap pelatihan pemasaran produk, mitra diperkenalkan dengan $e$ commerce yang meliputi penjualan produk melalui media sosial dan situs jual beli terkemuka. Kunci utama dalam pemasaran produk kopiah melalui e-commerce adalah penggunaan laptop dan handphone. Mitra diminta untuk mengunduh dan menginstall aplikasi media sosial, seperti Whatsapp, Facebook, Instagram, Twitter, dan situs jual beli terkemuka, seperti Tokopedia, Bukalapak, OLX, dan lainnya.

Tahap selanjutnya adalah praktik pembuatan akun usaha pada media sosial dan pembuatan toko online pada situs jual beli serta pengunggahan informasiinformasi penting usaha yang wajib ditampilkan pada tampilan utama akun media sosial dan toko online pada situs jual beli, termasuk nama dan label produk, nomor telepon yang dapat dihubungi, dan tampilan kemasan produk yang menarik. Metode workshop digunakan dalam penyampaian materi pelatihan agar mitra dapat berpartisipasi aktif selama pelatihan berlangsung. 


\section{Jurnal ABDIMAS INDEPENDEN}

Vol. 1, No. 1, Mei 2020

\section{Pelatihan Sumber Daya Manusia}

Tahapan pelatihan sumber daya manusia ini bertujuan untuk menumbuhkan dan meningkatkan motivasi kerja pemilik usaha dan pekerja. Termasuk di dalamnya, merubah pola pikir dan kecenderungan sifat pesimis sumber daya manusia yang ada terhadap industri kopiah menjadi lebih berkembang dan lebih optimistik. Pentingnya pembenahan ruang kerja yang teratur dan besarnya upah yang dibayarkan berdasarkan besarnya unit yang dihasilkan juga disampaikan guna meningkatkan motivasi dan produktifitas. Selama pelatihan berlangsung, mitra dapat membagikan keluhan-keluhan yang selama ini dihadapi dalam usahanya. Sehingga masalah tersebut dapat diselesaikan sedini mungkin dalam upaya meningkatkan minatnya untuk bekerja dan menekan tingginya tingkat turn over tenaga kerja.

\section{Pelatihan Pencatatan}

Tahapan pelatihan pencatatan bertujuan untuk memberikan kesadaran dan pemahaman terkait pentingnya pencatatan moneter bagi kelangsungan usaha. Pelatihan ini mencakup pencatatan sederhana keluar masuknya uang secara riil dalam suatu periode, seperti mitra seperti buku kas tabelaris, buku piutang, buku hutang, perhitungan harga pokok produksi, perhitungan laba rugi usaha dan sebagainya. Agar mitra dapat menentukan harga jual yang tepat untuk produk kopiah dengan menghitung biaya-biaya yang dikeluarkan selama proses produksi dan memproyeksikan besarnya laba yang akan diperoleh. Pelatihan ini menggunakan metode berbasis masalah konkrit yang dihadapi mitra dan terdiri dari 2 (dua) tahapan, yaitu pelatihan teknik pencatatan dan pendampingan intensif dalam praktik pencatatan usaha mitra.

\section{E. Evaluasi dan Pelaporan}

Tahap akhir dalam pelaksanaan agenda pokok PKM ini adalah evaluasi dan pelaporan. Tahap evaluasi dibutuhkan untuk mendapatkan informasi riil mengenai capaian target yang terpenuhi maupun yang perlu perbaikan pada 
kegiatan selanjutnya. Evaluasi dilakukan dengan mengadakan rapat refleksi antara mitra dan tim, data semua tahapan yang tercatat dalam logbook, dan hasil observasi tim selama program berlangsung. Hasil dari tahap evaluasi tersebut digunakan sebagai dasar dalam pelaporan akhir.

\section{HASIL DAN PEMBAHASAN}

Pelaksanan kegitan pengabdian ini meliputi pelatihan pemasaran produk melalui e-commerce dengan pemanfaatan media sosial dan situs jual beli terkemuka utuk dapat memperluas pangsa pasar yang berimbas pada meningkatnya pendapatan mitra. Selain itu, diberikan juga pelatihan untuk meningkatkan motivasi kerja pemilik usaha serta pekerjanya sehingga dapat menekan penurunan minat dan meningkatkan kualitas sumber daya manusia. Terakhir, kepada mitra diberikan juga bimbingan untuk dapat menerapkan pencatatan keuangan yang baik secara rutin.

Pelatihan dimulai dari mengenalkan kepada mitra tentang e-commerce beserta fungsinya dalam pemasaran produk pada era digital saat ini. Selanjutnya kepada mitra diperkenalkan satu persatu instrumen untuk menerapkan $e$ commerce seperti media sosial dan situs jual beli terkemuka,menjelaskan fiturfiturnya, kelebihan masing-masing instrumen, dan tata cara transaksi dalam jual beli online. Setelah itu diberikan juga kepada mitra pemahaman tentang cara pemasaran yang baik mulai dari kemasan, merk, dan model-model produk yang laku dipasaran saat ini.

Setelah proses pelatihan pertama, selanjutnya kepada mitra diberikan bimbingan tentang cara menigkatkan motivasi kerja karyawan. Misalnya dengan mengatur kembali ruang kerja untuk menciptakan suasana kerja yang kondusif, kemudian pembenahan upah dan gaji yang mana dapat membuat karyawan lebih merasa dihargai. 


\section{Jurnal ABDIMAS INDEPENDEN}

Vol. 1, No. 1, Mei 2020

Terakhir, yaitu pemberian bimbingan dalam memahami pencatatan keuangan yang baik. Masalah terakhir ini merupakan hal yang krusial dimana selama ini mitra memang belum melakukan pencatatan dengan baik terkait kegiatan produksi dan penjualan barang produknya. Pelatihan dimulai dari cara menglasifikasikan biaya seperti biaya tetap dan biaya variabel. Biaya variabel dari produksi kopiah ini seperti kain, songket, benang, lem,busa, label merek, serta listrik untuk mesin dan penerangan. Sedangan biaya tetap misalnya depresiasi mesin jahit, mesin obras, dan mesis bordir. Dari tahap ini mitra diarahkan untuk dapat mengendalikan biaya-biaya produksinya.

Selanjutnya setelah jenis biaya diketahui, pelatihan dilanjutkan dengan memberikan pemahaman tentang cara pencatatan biaya-biaya produksi tersebut agar mitra memiliki sistem pembukuan yang baik. Kemudian dilanjutkan dengan cara untuk mencatat penjualan yang mereka terima. Dari tahapan ini mitra diharapkan mampu memproyeksikan penjualan mereka keepannya berdasarkan catatan masa lalu.

\section{KESIMPULAN DAN SARAN}

\section{Kesimpulan}

Melalui program pengabdian kepada masyarakat yang telah dilaksanakan, dapat ditarik kesimpulan bahwa:

a. Kegiatan pelaksanaan pengabdian pada masyarakat dengan judul Pelatihan Peningkatan Pendapatan dan Pencatatan Usaha pada Industri Kopiah di Kediri Lombok Barat.

b. Mitra dapat memahami pentingnya pemasaran melalui e-commerce dengan memanfaatkan media sosial dan situs jual beli online serta mengikuti perkembangan selera pasar terhadap model kopiah terkini.

c. Mitra dapat memahami pentingnya meningkatkan motivasi kerja karyawan untuk menghasilan produk yang berkualitas dan bersaing. 
d. Mitra dapat memahami pentingnya pencatatan atas setiap biaya produksi dan penjualan yang diterima untuk keberlangsungan usaha mitra kedepannya.

\section{Saran}

Saran yang dapat disampaikan adalah sebagai berikut: 1) Kegiatan pengabdian ini dapat dilaksanakan didaerah lain; 2) Jangka waktu pelaksanaan pelatihan dapat diperpanjang; 3) Perlu adanya kegiatan pengabdian lebih lanjut dengan materi pelatihan yang lebih mendalam.

\section{DAFTAR PUSTAKA}

Abdullah, Fahri.2012. Manajemen Pemasaran. Rajawali Pers.Jakarta

Purwaji, Agus.2017. Pengantar Akuntansi. Salemba Empat. Jakarta

Janrosl, V. S., Sari, D. E., Tuwonaung, S. T. 2017. Pembinaan Financial Report Pada Pelaku UMKM Kecamatan Sagulung Batam. Jurnal Pengabdian dan Pemberdayaan Masyarakat, Vol.1, No.2.

Putri, Z. E. 2018. Pemanfaatan Jaringan Sosial dalam Pengembangan Usaha oleh Pelaku UMKM (Studi Kasus 8 UMKM pada Sentra Makanan Rendang di Kelurahan Sungai Durian, Kecamatan Lamposi Tigo Nagari, Kota Payakumbuh). Jurnal Sains Sosial dan Humaniora, Vol. 2, No. 1.

Sujarweni, V. W. 2016. Implementasi Penentuan Harga Pokok Produksi Untuk Mencapai Laba Optimal (Studi Pada Sentra UMKM Industri Bakpia Di Wilayah Minomartani Sleman Yogyakarta). Jurnal Riset Akuntansi \& Keuangan, Vol.4, No.3, pp 12-26. 